\title{
Gandhi on Caturvarṇa and Niṣkāma Karma: A Re-interpretation
}

\author{
Enakshi Ray Mitra ${ }^{1,2}$
}

Received: 31 March 2020 / Accepted: 24 August 2020 / Published online: 5 September 2020

(c) ICPR 2020

\begin{abstract}
Gandhi's writings on the issue of Caturvarṇa, despite their apparent lacunas, dogmatic tones and seeming inconsistencies, are available to a convincing reconstruction. With this purpose in view, the first section of this paper will attempt to give an anti-foundational reading of Caturvarna - where varna is seen to be based neither on the different proportions of the three gunas (sattva, rajas and tamas), nor on a system of hereditary professions, but as abstract dimensions that are not mutually exclusive-and at best serves to give an orientation to our cognition and actions. This reading, while borrowing heavily from Shri Aurobindo's reading of Caturvarna, will seek to give it a more neutral and expansive direction, shorn of all associated suggestions of intransigence and empirical contingencies, in order to effect the best possible synthesis with Gandhi. The second section of this paper will concentrate on appropriate portions of Gandhi's commentary on Git $\bar{a}$, trying to track down Gandhi's reservations against any psychological determinism with respect to varṇa. His direct but scattered observations on varna and caste will be addressed in the last section-to see how far our neutral reading of Caturvarna can be responsibly reconciled with his distinction between varṇa and caste-indicating a way to dissolve the Gandhi-Ambedkar debate on varṇabheda and jātibheda. Overall, this paper attempts a paradigmatic reconstruction of Gandhian Caturvarṇa in the light of his approach to the notion of niṣkāma karma.
\end{abstract}

Keywords Three gunas $\cdot$ Paradigmatic $\cdot$ Psychological determinism · Antifoundationalist · Caturvarṇa $\cdot$ Niṣkāma karma

Enakshi Ray Mitra

enakshimitra21@gmail.com

1 Department of Philosophy, University of Delhi, Delhi 110007, India

2 New Delhi, India 


\section{Setting the Need for an Anti-foundational Reading of Caturvarṇa}

We all know that the caste system as it is practised in India is a distortion of the original principle of Caturvarna formulated in the Gitta and Vedas. ${ }^{1}$ In order to understand the process of distortion, we have to address a well-known symbolic imagery (figuring in the Rgveda) associated with the Caturvarna, and also a psychological theory of four personality types constituted by a specific proportion of trigunas, viz. sattva, rajas and tamas. Both the imagery and the psychological theory will be ultimately displaced by a more neutral and anti-foundational reading of Caturvarna, where the four varnas turn out to be the four ethical directions or dimensions of carrying out our cognition and actions. Being four aspects or dimensions of the same content or locus - they will turn out to be not mutually exclusive. Thus, the same human character may have one aspect or direction as more pronounced than the others. In other words, each of these so-called varnas constitutes a personality type or svabhāva, each type is a marked disposition that is rightfully allowed to follow its own action or svadharma.

Hopefully, there will be no psychological determinism here-rather the criterion of morality is to facilitate the marked aspects or dispositions of one's character and to navigate them to their fullest efficacy, which in the long run turns out to be the deliverance of nișkāma karma. Thus, ideally speaking, what the society is grounded on are the personality types or svabhāva-which are constituted by specific aspects or orientations of the trigunas - which in their turn are articulated by the criterion of morality.

After a brief recount of the well-known imagery of Caturvarṇa, we shall pass over to a concise narration of the tripartite guna-karma basis of Caturvarna in the Gìtā line-which also happens to be in consonance with the Yogasūtras. ${ }^{2}$ Some basic problems in this traditional guna-karma basis of varna will ultimately take us to a conceptual or paradigmatic reading of this issue in the style of Aurobindo.

\section{Imagery of Caturvarna}

The symbol of Caturvarna mentioned above was captured in the Purusasukta of Rgveda where we find an imagery of a Universal Spirit producing four orders or types of men. An English rendition of this Rk would be roughly as follows:

His head was the Brāhmana; of His arms Rājanya (Kșatriya) was made; then His thighs were the Vaiśyas; of His feet were born the Ś $u d r a{ }^{3}$

\footnotetext{
${ }^{1}$ For writing this section, I am chiefly indebted to Basu (1995) I have been guided by this paper to draw the essential points of Aurobindo's theory from Ghosh (1997a) Chapters I, XI and XIII; (1997b) Chapters VIII, XIV, XVIII, XIX, XIX, XX; and (1999) Chapter III.

2 I have used Venkateshananda (2001) for his translation and commentary of Patanjali's Yoga Sütras.

${ }^{3}$ For the original couplet, see Web: www.sanskritweb.net/rigveda/rv10-086.pdf.
} 


\section{Triguṇa and Karma: Psychological Basis of Caturvarṇa}

Karma as conceived in the Gìta broadly stands not only for voluntary actions, but covers the harmonious function of a living and cognizing organism, where the lifebreath (prāna), the sensory and the motor organs, the mind, ego and buddhi-all cohere in the growth, reproduction and preservation of the human body. (Git $t \bar{a}$ III.5) ${ }^{4}$ In so far as a Yogi can intentionally stop his life-sustaining activities like respiration, digestion, blood circulation, etc., they too are deemed to have a volitional character and hence termed as 'karma'. Any cognition or volition leaves its subtle impression (samskāra) on the subconscious mind stuff (citta) and is enlivened on appropriate occasions. Samskāras are like sediments underlying explicit cognitions and volitions - in a manner that every action and cognition scoops up a handful of clay from a pot—which again settles down as a new layer on the old sediments. The word 'trigunaih' in the above-mentioned verse clearly suggests that according to Git $\bar{a}$, it is an interplay of the three gunas_-viz. sattva, rajas and tamas - that direct all actions. For this samskāra theory, it is the continuous generation and revocation of samskāras that make our cognitions and engagements smooth and unhindered.

Let us understand how exactly the personality types are created in accordance with the three different directions and dispositions of the gunas. A guna is a universal mould of our karmaśakti, the latter being the power with which our sense organs and motor organs are equipped for coping with the environment. One disposition of this karmaśakti that maintains the reciprocal balance of several qualities in an even equilibrium through the means of intellection is termed as the sattva guna. The rajas helps navigating the karmaśakti, whereas tamas is the term for our inertial tendencies marked by deficient intelligence. All characters are composed of these three gunas, one or other of which gets primacy over others in some stage of our life.

The primacy of sattva (in maintaining a balance between the three gunas) is marked by a tendency to bypass the exuberance of external facts and incidents to withdraw into the theoretical or general principles that bind the former. A sāttvik personality accords importance to the empirical richness of data only to the extent to which he can derive the general principles underlying the superficial variety of incidents. If a sāttvik personality is also marked by an appreciable presence of rajas, he will be equipped with the physical prowess and pragmatic skills to apply the abstract principles of knowledge and ethics to the concrete situations-fighting effectively against conflicts and opposition. But an untempered intensity of rajas amounts to an attitude of unqualified egotism, which naturally erupts in such activities as killing, conquering, selfish consumption at the cost of others. Such personalities, only if channelized in the sāttvik direction, can attain spiritual control, spiritual bliss and power. On the other hand, a tāmasik personality yields inertly to the pressures of the

\footnotetext{
${ }^{4}$ I am specially indebted to Aranya (1369 (Bangabda)) for writing the account of samskāras, karma and karmaphala. The account ultimately falls back on the Yogasūtras - and the relevant insights about this psychological theory are scattered all over the body of the sūtras. However, specific details about different kinds of samskaras, memory and karmaphala can be tracked down in Chapter II, verses 12-15, Chapter IV 8-10, while more generic inputs figure in Chapter I, verses 6, 11, 18, 19, 34, 43, 50. (See footnote 2).
} 
external world, without making any effort to resist or recast the imposing barrage of sensory stimulations into a constructive direction. An unqualified concentration of tamas cannot possibly be turned into a balanced synthesis of the three gunas,- - for a minimal presence of the sattva and rajas would at most enable him to assimilate the minimal character of the sensory stimuli-sufficient for his basic survival—not adequate for the assimilation of principles and laws of a higher level of generality.

Further sattva is held to produce pleasure, rajas pain and tamas indifferencewhich shows that varṇabheda is not only due to gunabheda but to karmabheda as well. To speak at a more concrete level, the karmas of a Brāhmana are yājana, yajāna, adhyayana and adhyāpanā, while those of the Kșatriya are the protection of people from external and internal disturbances; Vaiśyas should engage in commerce and agriculture, while the duties of the Sudras are to render service to the upper varnas. 5

Thus, the tripartite division of personalities is constituted by a tripartite division of guna-karma configuration. In more specific terms the specific pattern of the three gunas for each person constitutes his svadharma. Subbannachar ${ }^{6}$ has charted out the three gunas with respect to the pattern of their possible intermixtures.

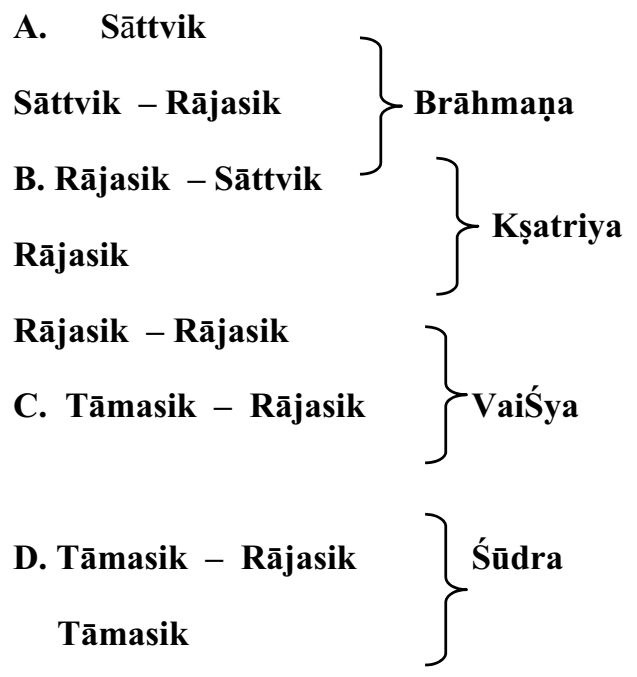

Thus, this interpretation enables us to come out at least from the old imagery or the physical symbol of the Rgveda and reconceive Caturvarna-not as determined by the professions inherited by one's forefathers, but rather by the psychological principle of one's svadharma. It is this svadharma that constructs the moral criterion of spiritual elevation.

\footnotetext{
5 See Chakrabarti (2010) pp. 36-37.

6 Subbannachar (1966). (Table 9, pp. 259 \& 323), also cited in Basu (1995) endnote 14.
} 


\section{Theory of Samiskāras and Its Role in Determining Varṇa}

The Yogasūtras ${ }^{7}$ speak of two kinds of samskāras-(1) smriphala or vāsanā and (2) trivipāka. Vāsanā or desire is again of three kinds- the desire(unconscious) for jāti (birth), desire for āyu (life span) and desire for bhoga (pleasure and pain) —all of which are characteristically passive, for they can simply reproduce themselves in memory - they cannot produce a new construction. Once the raw elemental force of our sensory and motor organs falls into the three moulds of vāsanās or desires, what we have is the creative functioning of trivipāka, that being directly attached with the powers of our sensory and motor organs leads to volition (ceșțā), subsequently bringing relevant changes in our instruments or organs themselves. In fine vāsanas produce the path through which the trivipāka geared to the instrumental powers can navigate to produce further actions and further samskāras-not in the present birth, but in the subsequent ones.

The Yogasūtras with which the precepts of Gitta on the principal issues of trigunas, karma and samskāras match roughly speak of two types of karmaspuruṣakāra and bhogabhūta. The latter kind comprises those actions where the agent's will is overpowered by the functioning of his sensory and motor organsfor instance, the activities of digestion, respiration, falling down on the ground, being physically compelled to do something, habitual and impulsive actions. These actions are determined by past samiskāras and external forces. Puruṣakāra on the other hand are voluntary action in the true sense of the term that characteristically resist sāmskārik impulsions. Karmas once performed have already generated a repertoire of samiskāras which in their turn must produce their respective phalas (consequences)—phalas which the agent must suffer-irrevocably, inviolably. If one habitually takes to stealing or frequently gives vent to uncouth passions, these actions will produce their respective samskāras that will go on producing further consequences, unless the very nature and direction of those samskāras (caurasaṃskāras and krodha samiskāras ${ }^{8}$ ) are reflected upon and steered to a new channel. It is only then that the new trend of samiskāras (acaura- and akrodha samiskāras) will start producing a different set of effects, but not before the previous caura and krodha samiskāras have run the full track of their production. Thus, it turns out that the Indian psychology admits two levels - the first level where actions and cognitions are caught into a deterministic law of causation, and the second level where the human mind can perform an operation with the samskāras themselves to channelize them into a different direction.

The content of the verses of Gitta III 33-43 roughly matches with the above theory of the Yoga. Let us paraphrase Gandhi's rendition of verse 37 and 41-43. Lust and anger, kāma and krodha are the 'two great energies of man [that] drive him to sin'. When man realizes God, 'his mind will be under His control, not swayed by the sense'. Gandhi further explicates that 'Controlling the self by the

\footnotetext{
7 See footnote 4 .

8 These phrases can be translated, respectively, as 'cleptomaniac and wrathful dispositions'.
} 
Self' (samistabhya'tmānam ātmanā-verse 43) means 'overpowering the demoniac impulses in the mind through the Atman, that is through the Godward impulses'.

It is argued that the nature of a jiva is an outcome of two factors-the one is the samskāra of the previous birth and the other is the environmental factors arising out of education and good association in the present birth. That the human nature changes due to the complex intermixture of these two factors is clearly registered in $G \bar{t} t \bar{a}$ where it enjoins that if the Brāhmaṇic characteristics like Śama, dama, etc., are found in varṇas other individuals than the Brāhmaṇas then they are to be deemed as Brāhmaṇas as well. Many scholars are of the opinion that the so-called varṇabheda cannot be traced in the Vedic era. Rgveda contains unambiguous statements about the same family members engaging in different activities. 'Look here, I am a strotrakāra, my son is a medical practitioner, i.e. vaidya, and my daughter is a yababharjanakāri, i.e. a cook. One can find similar ideas in Aitereya, Chāndogya and Śatapathabrāhmaṇa. It is to be further noted that in Śatapathābrāhmaṇa as well as in Taittirīya there is no mention of the Sūdras - clearly showing that the notion of Sūdras was contrived and introduced later in the social mainstream. ${ }^{9}$

At this juncture the guna-karma theory of varna gets challenged by the following two options. The first is the aposteriori thesis that we are born first and then acquire the guna and karma through the course of our present life, the second is the apriori thesis that we are born with the samskāras of the respective varnas. ${ }^{10}$ The Git $\bar{a}$ theory as well as the Yogasūtras-with their rigourous distinctions between two types of samikāaras and karmas - with their substantial ontology of trivipāka and bhogabhūta karmas - clearly upholds the apriori theory. It is indeed a common empirical fact that we see people change their karmas and gunas at different stages of their life-sometimes quite radically and dramatically, but never in an abrupt or sporadic fashion that would give the impression of a total chaos or disorder-where everything follows from everything, and hence nothing follows from anything. This consideration apparently lends a strong support to the apriori theory of the guna-karma vibhāga of Caturvarṇa. On this theory, every action or cognition (in so far as it falls under the category of the bhogabhūta karma) is caused by, and itself gives rise to, an appropriate samskāra-thus producing an infinite stretch of sedimentation that runs through the entire series of births and rebirths. However, the theory of Purusakāra has to allow that a person has the ability to negotiate with his pre-given samskāras and to recast them to create a new flow. Otherwise if the nature and extent to which the samiskāras can be moulded are already inscribed in the pre-given samskāras, then the very notion of Purușakāra as well as the promise of freedom from an apriori sediment will turn out to be a hoax. Indeed, when the Shastras enjoin specific duties to specific varṇas with a moral predicate of 'should', it virtually negates a psychological determinism and commits itself to the possibility of outgrowing these varnic norms.

\footnotetext{
${ }^{9}$ See Chattopadhyay (1401 (Bangabda)) specially p 703, and also Chakrabarti (2010) for other such details.

${ }^{10}$ See Chakrabarti (2010) for constructing these two options, as for other relevant points of defence as well.
} 


\section{Defects in the Tripartite Guṇa-Karma Basis of Caturvarṇa}

First, it seeks to ensure that no action or cognition occurs without a sāmskārik base; otherwise, it would be a random occurrence magically shooting off in a vacuum-which cannot meaningfully be ascribed to the relevant subject as his action or his cognition and nobody else's. But how would then a purusakara that modifies the samskāras themselves take place-without having its base in the previous samskāras? The problematic character of being inauthentic and agentless will detract the purusakaras from their crucial role in moral philosophy. Secondly, since vāsanas and trivipāka are by definition unconscious, the talk of the present action or cognition reviving a similar samskāra does not make sense. The purported similarity has to be judged by the subject and the agent - and for this both the items of the similarity relation-viz. the present action as well as the past samskāra has to be (per impossibile) consciously present to the subject-a crucial requirement that cannot be satisfied by the samiskāra theory. An unrecognized similarity floating in the air and hauling up the relevant samskāra does not have any explanatory weight. Overall, the picture of each person being born with a semi-solid sediment of samskāras, having a definite proportion of the three gunas, with a parallel meta-level capability of modifying this sāmskārik fluid seems to be a problematic piece of ontology. In this theory the gunas do not figure as exclusive essences, but as specific categories of intermixtures with specific directions, and each type of intermixture constitutes a determinate type of personality. Instead of solid hard entities we have fluids or flows, but each flow is determined with respect to the exact nature and extent to which it flows. Thus, each of the varnas now is reconstituted as a characteristic fluidity and this fluid-metaphysics cannot avoid the flaws of psychological determinism. ${ }^{11}$

It is said that the course of Indian history took a perverse turn where the psychological as well as the moral principles of varnavyavasthā got completely obscured. The conceptual or paradigmatic basis of the four personality types was forcefully contrived into some artificial sects of the society. What was presented in the Rgveda as simply an persuasive imagery or a metaphor underwent an unimaginative and literal degeneration. The Pundits and priests became the caricature of Brāhmaṇatva or sattva guna, the idle and despotic landowners came to represent rajas or Kșatriyatva, the greedy merchants were equated with Vaiśyatva (a rajas-sattva synthesis), and lastly the half-fed labourers were reduced to Sundratva or tamas. Now it needs to be noted that this very fact of the original ethical and religious principles of Caturvarna degenerating into perverse masks or caricatures is again due to the actions of men with specific personality types, where each type is constituted by a specific fluidity of the trigunas. Thus, the psychological determinism embedded in the guna-karma basis of Caturvarna is fraught with multiple layers of inconsistencies.

\footnotetext{
11 See Mitra (2014) for a more detailed account of the theory of karma and samskāras and its flaws, pp. $62-67$.
} 


\section{Constructing an Anti-foundational Approach to Caturvarṇa}

To avoid this determinism, we have to re interpret Caturvarna in a still different way, so that a varna or a personality type would not be identified with a pattern of fluidity. The four principles are now reformulated as A. Wisdom (Prajñā) or the knowledge of Ultimate Reality, B. Ultimate Power or Śakti, C. Harmony (Samhati) or the sustenance of various parts in a cohesive balance, and D. Work (Karma), i.e. achieving efficiency and completeness in labour. ${ }^{12}$ The psychological determinism that marked the previous theory of varna should be revised to incorporate purușakāra that enables each individual to channelize his samskāras to new directions, without being encased in a pre-given network of samiskāras, and without implicating two levels (a first level and a meta-level) of cognition and actions.

What is the exact flaw in equating a personality type with a specific pattern of flexibility of the gunas? It is not that one guna penetrates into another, rather one supposedly fixed proportion of gunas penetrates into another supposedly fixed proportion. In order to appreciate how one kind of fluidity penetrates into another kind of fluidity, one has to re-read the four new principles-Prajñā, Śakti, Samihati and Karma - as to how they blend intractably into each other. Pure intellection, even in the shape of a conscious and deliberate attempt to withdraw a theory from all possible applications is itself cast into an applicational mould, for a theory whose preliminary routes of application are not incorporated into the theory fails on both moral and intellectual grounds. It fails on moral grounds because the formulation of the theory is not motivated for the sake of knowledge, rather it is the egoistic passions that impel one to submerge the applicational flaws in his theory; it fails on intellectual grounds because a theory which does not incorporate the ceteris paribus clauses of application is failure as a theory itself, and this is not merely a peripheral defect pertaining to the sphere of application.

It is for this reason that the intrusion of Kșatriyatva into Brāhmanatva is necessary, for Kșatriyatva should be seen as the cognitive power (and not merely muscle power) and contextual sensitivities to implement theories in the face of all resistance and oppositions-whether they are offered by nature or man. Similarly, a person who is capable of increasing productivity should not be doing it for generating money for the sake of money, i.e. amassing a heap of papers or metals. Increasing money should be a symbol of increasing production and a due recognition of a person's productivity. Similarly, love for work is not passive unimaginative labour or blind obedience, it needs to infuse innovative ideas into labour-thus bridging the gaps that often crop up between theory and practice. Looked at in this way, it connects directly to Kșatriyatva, extending the general conception of the ceteris paribus clauses to their concrete implementation at the ground level. This is how the work of a technician and a labourer blends with that of a theoretician, this is how Karma blends with Prajñā and Śakti, and all are synthesized under the principle of Samihati.

\footnotetext{
${ }^{12}$ Insights about these four principles can be related to Kapali Sastry (1948), pp. 95, 98-99. Also cited in Basu (1995).
} 
Thus, the Caturvarnas turn out to be four paradigms with no ontological correlates. A ruler used to measure length only functions through an active exercise of shoving out the unwanted excess of breadth, depth, colour and texture - of both the ruler and the measurable object-an exercise which does not draw anything from a supposedly immaculate length of the ruler.

If we turn back to the original imagery of the Purusa whose limbs generated the four varnas, one can see that the four organs of the Purusa are merely the four dimensions and directions of our cognition and actions. They are four ways of freeing ourselves from constraints-whether they are our passions and inclinations or the external impositions - and work solely through the principle of inner necessitation.

Aurobindo seems to wind up with his insistence that the fourfold powers have to be harmonized and integrated around the soul force or Âtman which surpasses the ego. Now we want to suggest some revisions of Aurobinda's paradigm to give it a more neutral character so that Gandhi's approach too can be reconciled with this reading. In this reading the significance of Caturvarna and the language of Caturvarna turns out to be is somewhat like this. On the one hand, the different varṇas become different paradigms - one is to discard breadth to focus on length, the other is to discard length in favour of breadth, still another is to discard both length and breadth and just to concentrate of the depth. On the other hand, there is an equally compelling demand of one paradigm penetrating into another. Ossifying the four paradigms of varna into real entities - real groups of humans-was a degenerative phase of Indian history; similarly, deliberate nullification of paradigms amounts to the perverse practice of using elastic rulers for measurement, or contriving water drops or gas waves as units of counting. On the one hand, there is an unavoidable need for knowledge to recoil into itself, to the extent to resisting the exuberance of empirical data assuming the shape of being the primary objective; on the other hand, both the demand of mere intellectual harmony empty of content and the rhetoric of servility or unquestioning obedience (taking the garb of pure sattva and pure tamas, respectively) should be resisted from being ends in themselves. The exact nature and extent to which the four paradigms should allow and resist interpenetration cannot be decided by external constraint-be it the psychology of impulsion or the logic of utility - but should be motivated by inner necessitation or the principle of nișkāma karma.

\section{Reading Gandhi's Commentary of Gīta $\bar{a}^{13}$ : In View of the Paradigmatic Principle of Caturvarṇa}

Browsing through Gandhi's commentary on Git $\bar{a}$ - with respect to certain selected portion - can enable one to effectively reconcile his view of varna with our paradigmatic reading of the same. Gandhi elaborates IV 13-what is distinctive of a Brahmin is that he knows Brahman, and lives most in the consciousness of God,

\footnotetext{
13 Strohmeirer (Ed.) (2009) All references to Gītā have been marked as the verse number in decimal notation preceded by the chapter number in Roman letters.
} 
and imbibes the duty of helping people to realize God. Gandhi emphasizes that '[b]esides this particular gift, he will also have the qualities of character that mark the other varnas'. And it is this context that Gandhi said that the súdra's special dharma is service, which he needs to combine with the spirit of yajña, or 'the motive of public good'. Gandhi further comments: 'If we regard the person who cleans lavatories as lower and another who reads the Gita as higher, that will be the end of us. ${ }^{14}$ Again in his interpretation of III $35^{15}$ he observes that should a person settled in a particular profession-say a sweeper-allow himself to be drawn away from his duty to become an accountant he would himself be lost and put the community in danger. What needs to be noted is that Gandhi does not translate 'svadharma' as one's 'law' or 'psycho-physical make up', ${ }^{16}$ but renders it simply as 'one's duty'. He also observes that 'before God the work of man will be judged by the spirit in which it is done, not by the nature of the work'. ${ }^{17}$ The fact that he does not render the term as 'one's law' suggests that he does not relate varna deterministically with a psychophysical foundation that is given in birth.

We can take such observations as suggestive occasions to lay out the interesting connection between violating one's svadharma and violating the principle of niṣkāma karma. It is often said that the frog which tries to blow himself up in order to grow as big as a bull explodes itself to death because the svadharma of a frog is to remain a frog. Milk may be better than water, but a fish that insists on living in milk will die. Sun is the source of energy that the earth gets, but we will not survive an attempt to leave the earth and be close to the source, because our svadharma is to live on earth. One may not believe in milk or fire as having unchanging essences, one may not believe in a metaphysical reality of space that encloses every object in an ethereal boundary, but these anti-metaphysical insights should not be stretched to the absurdity that one can bloat one's frog size to that of a bull. This kind of fallacy is on the same footing with that of traversing space from one point to another without traversing the distance in between. That space qua an external container of objects is unreal, that every space is penetrated by every other, does not consist in magically bloating up the size; and ironically, bloating one size to any other loses sight of the inherent porosity of space and spatial boundaries. It labours under the false imagery of one spatial boundary increasing into another, and this inflammation does not operate by absorption of more and more space, but in magically spreading out the smaller-space container, within which the smaller body was supposed to be encased, into a larger container. Such efforts sway under the impression of putting more content into the container, so that the previous walls would recede to allow more volume within the container-all this happening in the spatial containment

\footnotetext{
14 Ibid, pp. 59-60.

15 Śreyān sva-dharmo viguṇah para-dharmāt svanușțhitāt/svadharme nidhanam śreya para-dharmo bhayāvahah'. I have used Radhakrishnan (1949) for citing original verses from Gītā.

16 This is how Radhakrishnan renders the crucial term 'svadharma'. See Radhakrishnan (1949) pp. 146147.

17 Strohmeirer, J (Ed), pp. 50, 51.
} 
model. And such an unnaturally flawed operation cannot be motivated by the sake of duty, i.e. it cannot be performed in the niṣkāma style.

In all these contrived exercises of bloating sizes, ossifying or liquidizing paradigms, it is the immense load of our passions and desires that breaks up the immaculate oneness of space into fragments. Performing actions in a desireless way can only obtain when actions, intentions and consequences are absorbed into a smooth continuity, and this will not accommodate any invalid attempt to outgrow the natural course of one's faculties, rather one should let one's rule of action space out gradually into the intention, action and consequences. ${ }^{18}$

This internal relation between action, intention and consequences is clearly seen in the principle of nișkāma karma which enjoins us to abandon the external and contingent consequences (naimittik phalas) of an action, and never the natural or internal (svābhāvik) ones. The Yoga system as well as the Gìtā theory of karma, samskāra and karmaphalas take care to clarify that the irregular and external contingencies invariably associated with our actions are not the phalas in the strict sense of the term, it is only the internal and natural consequences that are to be considered to be the karmaphalas. The exact distinction between these two kinds of phalas can be explained by three examples. (1) A person's scholarship leading to his cerebral excellence, (2) drinking water contaminated by a COVID-19-infected person due to the samskāras of ignorance (3) the action of planting a sapling giving rise to a feeling of pleasure and expectation. These are the natural or internal consequences of the actions or the relevant samskāras-while the consequences like getting a post of professorship in case of (1), or contracting COVID-19 disease in the case of (2) or the fruition of the plant in case of (3) are external contingencies. It is the ways we are affected by the external conditions (and not the conditions themselves-viz. those of having a social reputation, contracting COVID-19 disease, fruition of the plant, etc.) that constitute the natural consequences or phalas of an action.

The injunction of performing actions in a niṣkāma style should be understood in the light of the relevant distinction between natural (svābhāvik) phalas and accidental (naimittik) phalas of our actions. The negative particle 'mā' in Gìtā II $47^{19}$ connotes two kinds of negation. First, it makes a factual statement that the agents do not have any control (adhikāra) over the naimittik fruits. Secondly, it needs to be noted that the particle 'mā' cannot morally enjoin us to renounce the svābhāvik phalas - say the cerebral excellence generated by one's scholarship, or the idea of the sown sapling budding in its due course. The natural consequences are conceptually embedded into the actions themselves, and hence, the injunction of renouncing them does not make sense. What the second meaning of 'mā' applies to is the moral injunction of renouncing the passionate excess of a craving (or repulsion) for the svābhāvik phalas—not renouncing the svābhāvik phalas themselves.

Gandhi's translation and commentary of Gîtā II 47 and 48 may be read as falling in with the distinction between the svābhāvik and naimittik phalas. When Gandhi says : 'Let not thy motive be the fruit of the action', when he says that 'the reward

18 See Mitra (2014) for an elaboration of this point.

19 Karmaṇy eva'dhikāras te/mā phaleṣu kadācana/mā karmaphalahetur bhur/mā te sañgo'stv akarmaṇi. 
of the work is entirely for Him to give', Gandhi meant not the svābhāvik phalas that are blended with the very action, but the external and contingent consequences- the occurrence or non-occurrence of which are actually beyond our control. For Gandhi, performing a nișkāma karma would involve the difficult feat of delinking the apparently svābhāvik phalas from the actions and reconceiving them as the naimittik one; and this involves displacing the latter from the realm of conscious intention and leave it to Nature or God. Giving away the naimittik fruits to God amounts to recasting what seems to be a consciously intended action into a reflex or spontaneous action. In our present example, getting a lucrative job (on the basis of scholarship) is not what can be consciously intended-it rather stands on the footing with reflex or spontaneous actions. If one thinks that the task of protecting our eyes with the lids is what he has consciously designed he has to reconceive that seemingly intentional action into a reflex action that falls within the realm of Nature or God. For Gandhi, giving away the external rewards of action to God is to realize one's slender and spontaneous link with Him, and it is in this sense that the actions geared to merely the naimittik fruits are comparable with reflex actions. Gandhi's commentary on II 48 also is an innovative recreation of the injunction not to give up the svābhāvik fruits, but to give up our attachments for it. '[W]e should not be attached even to a good cause. Only then will our means remain pure and our actions, too'.

We have to understand how the artificial distortion of varna paradigms misconceives naimittik phalas of an action as its svābhāvik ones, thus violating the principle of nișkāma karma. The principle of Prajñā-say in the discipline of microbiologyevenly balances the theory with conceptual possibility of its application-without diluting the theoretical rigour for the sake of gaining the actual fruits of application. The principle of Śakti will articulate the difference between the purely conceptual possibility of application and the path of its actual applications, while the principle of Karma will turn the actual possibilities into concrete realities. All these paradigms of varna complement each other in a way that any of these attempting to outgrow the others results in importing foreign elements-virtually destroying the entire fourfold synthesis. Using the theory of microorganisms for manufacturing viruses (for destroying rival nations) is as much foreign to the discipline of virology as the external motivations of lust for power that triggers off this worst kind of extrapolation-i.e. the worst kind of sakāma conflation of the svābhāvik with the naimittik.

Gìtā XVIII 41-44 does speak of the duties of Brāhmaṇa, Kṣatriya, Vaiśya and Sūdra-being distributed according to their innate qualifications (svabhāvaprabhāvair guṇair). Gandhi adopts the standard translation of śama and dama-as serenity and self-restraint, 'tapas' Gandhi translates as a procedure to keep body, speech and mind under control by hard discipline. Forgiveness he amplifies as wishing well, even for a person who may have hit us with a stone, straightforwardness he translates as having no impurity in one's eyes. Here one may legitimately claim that having no impurity in one's eyes is not to see the people under the lens of false categorization (of the fourfold sects) - and this for Gandhi is behaving decently. Knowledge and discriminative knowledge ('jñānam, vijñānam') Gandhi translates as knowledge based on experience and not bookish dry knowledge-which supports our ultimate reading of the Caturvarnas as notional 
paradigms. Brāhmaṇatva is characterized by Gandhi as a theoretical or intellectual orientation to all phenomena, not overpowered by superficial empirical details. Faith in God (āstikya) is mentioned last among the list of the defining characteristics of a Brāhmaṇa. Serenity is calmness, equanimity, composure-which roughly stands for the quality of not being too elated nor too dejected due to external circumstances, thus keeping a balance of emotions. Gandhi explains that some qualities like serenity and self-discipline with a bad intent or selfish motives like winning prize competitions and wrestling matches fall back on the devotion to God to upgrade themselves as the defining characteristics of Brāhmaṇatva.

With respect to XVIII 43 Gandhi says that both a Brāhmaṇa and a Kṣatriya have to have the qualities like valour (śauryam), spiritedness (tejo), consistency (dhrti), resourcefulness (dākșyam), etc. This perhaps again shows that Gandhi did not believe in the trigunavibhāga foundation of Caturvarṇa. Gandhi adds that in this way every individual should display in varying measures the qualities associated with all the castes. (Italics added) The word 'should' shows that a person's character is not determined by a given structure of samskāras, otherwise the moral injunction to cultivate all the qualities associated with all the varnas will not arise. However, Gandhi has added the qualifier, viz. 'in varying measures', and he also adds that a person will belong to a caste the virtues of which he possesses in predominant measures. This would hopefully support out adoption of the fourfold principles of Prajñā, Śakti, Samhati and Karma and their modes of mutual complementation.

The way we have sought to assimilate Brāhmanatva with Kṣatriyatva-in the model of the synthesis between Prajñā and Śakti-may not tally with certain marks of Kșatriyatva, viz. 'śauryam', 'tejo', 'yuddhe ... apalayānam', as demanded in XVIII 43. When Galileo yielded to the pressures of the church to make false confessions about his scientific discovery-this might be a violation of the marks of Kșatriyatva-in so far as it is a glaring case of fleeing from battle. Hopefully Gandhi will argue that the machinations of a hostile society with vested interests for opposing the exploration of scientific laws of reality cannot be termed as a fair battle (nyāya yuddha), and from this perspective we can further insist that marks of Brāhmaṇatva or Prajñā-qua pure commitment to intellectual principles stands independent of muscle power or heroism that is patently supposed to withstand physical torment or even death for the sake of vindicating truth. ${ }^{20}$

\section{Gandhi's Observations on Varṇa}

The problem of eking out a comprehensive account from the bits and pieces of Gandhi's writings - often seeming to be inconsistent, incoherent and dissipative-is mainly because his view of Caturvarna evolved through a long process of transition.

\footnotetext{
${ }^{20}$ In this respect one can remember Galileo's pertinent observation, when he was admonished by his student Andrea, for making false confessions before the clergymen to save his own skin. When Andrea swore: 'Unhappy the land that has no heroes', Galileo replied: 'No, Unhappy the land that is in need of heroes'. See Brecht, B. (1939), Life of Galileo.
} 
Here we can selectively look at certain observations of Gandhi where he had discarded the caste system and the casteist version of varnāśrama in most unambiguous terms. ${ }^{21}$ By early 1930s, Gandhi had declared that caste was 'a handicap on progress' $^{22}$ and 'a social evil' ${ }^{23}$, and, by the 1940s he stated that it was 'an anachronism' ${ }^{24}$ which 'must go'.

Further he says: 'The Ashram does not follow the varnashram dharma. Where those in control of the Ashram will take the place of the pupils' parents and where lifelong vows of celibacy, non-hoarding, etc., are to be observed, varnashram dharma has no scope. The Ashram inmates will be in the stage of sanyasis and so it is not necessary for them to follow the rules of this dharma. Apart from this, the Ashram has a firm belief in the varnashram dharma'. ${ }^{25}$ This observation adequately shows that Gandhi did not believe in a dogmatic equation of varna and parental professions, nor perhaps with a specific type of triguna proportion that comes in the shape of a psychological determinism. The ashrama inmates already have the training to perform actions in the nișkāma model-through an inner determination free from external constraints of lust and greed, or pragmatic pressures and this equips them to see the Caturvarna in their dimensional character. While for Gandhi the obligation to follow the hereditary professions applies normally to people, in order to train their mind for the required paradigmatic reading of the varnas, the ashrama inmates already cultivating the dimensional principle of Caturvarna are exonerated from that obligation.

From our preferred standpoint, we can again look back at Gandhi's stand according to which untouchability itself is an artificial mask that thwarts the conceptual interpenetration of the four paradigms, thus stopping the moral principle of Caturvarna to operate. Actions patently become loaded with external factors like desire and vested interests of preserving untouchability-thus deviating from the ethical principle of nișkāma karma.

There are many occasions where Gandhi speaks simultaneously of removal of untouchability, equality, and the freedom to take a profession of one's choice-along with an injunction to adopt the profession of his forefathers. For instance, if we consider these reflections:

'[A Shudra] may not be called a Brahman in this birth. And it is a good thing for him not to arrogate a varna to which he is not born. It is a sign of true humility. ${ }^{26}$ 'I do not believe the caste system...to be an "odious and vicious dogma." It has its limitations and its defects, but there is nothing sinful about it...'27

\footnotetext{
21 For this I heavily rely on Nauriya (2006).

22 Gandhi (2015) Young India, 4-6-1931.

23 Ibid, Advance, 15-10-1932.

24 Ibid, Varnavyavastha, pp. 13-14.

25 Ibid, VARNASHRAM, p. 456.

26 Ibid, VOL. 40: 2 SEPTEMBER, 1927-1 DECEMBER, 1927, p. 484.

27 Ibid, VOL. 59: 13 JANUARY, 1933-9 MARCH, 1933, p.228.
} 
Further: 'The law of varna prescribes that a person should, for his living, follow the lawful occupation of his forefathers. I hold this to be a universal law governing the human family...'

But in the same passage he says: 'No one is precluded from rendering multitudinous acts of voluntary service and qualifying [educating, training] oneself for it. Thus... [a person] born of Brahmin parents and I born of Vaisya parents may consistently...serve as honorary national volunteers or honorary nurses or honorary scavengers in times of need, though in obedience to that law...I as a Vaisya would be earning my bread by selling drugs or groceries. Everyone is free to render any useful service so long as he does not claim reward for it'. ${ }^{28}$

Perhaps in the above excerpts Gandhi thought it obligatory to appreciate the sāttvik aspect of one's forefathers' profession and hence his injunction that everybody should follow his forefather's profession in its sāttvik dimension would have a universalizable character required for it to be a moral rule. It is in this sense that Gandhi as a son of Vaiśya parents can legitimately adopt the profession of a national volunteer or that of a scavenger without taking any remuneration. And in the light of the entire trajectory of this paper-from a psychological reading to a paradigmatic rendition of Caturvarna - we can take Gandhi's prescriptions about being humble about one's being born in a Sūdra family as connoting a sensitivity to the principle of Work and associated values of expertise in labour.

Again he says: 'I believe in varnashramadharma but I do not believe in castes. Varanashramadharma means that a man should find satisfaction in getting his livelihood from his ancestral occupation. ${ }^{29}$...I have devoted much thought to the subject of the caste system and come to the conclusion that Hindu society cannot dispense with it, that it lives on because of the discipline of caste. Societies all over the world are organized on the principle of caste or varnavyavastha. Our society was organized in this manner for the purpose of self-control, that is, for self-denial. ... So long as there are among human beings impulses which tend to a godly life and those which tend to a demoniac life, so long will the division of society into communities remain. It is a vain effort to replace this structure by one single community, ${ }^{30}$ One can read these observations not in terms of strict triguna proportions amounting to a godly personality versus a demoniac personality, nor in terms of different personality types smoothly complementing each other to form a cohesive community. Gandhi's reflections can only be adopted as a heuristic method-as a tentative tool or starting point to aid a non-foundational reading of these supposed psychological types.

To peruse through some more of his speculations: 'It is likely that at the end of it we shall all find that there is nothing to fight against in varnashrama. If, however, varnashrama even then looks an ugly thing, the whole of Hindu society will fight it... ${ }^{31}$ This clearly shows that Gandhi made a distinction between the psychological

28 Ibid, VOL. 40: 2 SEPTEMBER, 1927-1 DECEMBER, 1927, pp. 384, 385.

29 Ibid, VOL. 15: 21 MAY, 1915-31 AUGUST, 1917. P. 79.

30 Ibid, Vol. 15: 21 MAY, 1915-31 AUGUST, 1917, pp. 226-227.

31 Quoted in Nauria (2006), p. 1835. 
foundationalism and the paradigmatic reading of varṇāśrama — and ultimately abandoned the former in favour of the latter. The task of matching the reality of Indian society with the four categories was taken up by Gandhi as a programme, which as he clearly suggested, is to be discarded if facts do not meet the theory.

In April 1933, Gandhi declared on the basis of some authoritative texts that varna could not be perpetuated or determined merely by birth. He argues: 'These and numerous other verses from the shastras unmistakeably show that mere birth counts for nothing'. ${ }^{32}$ He could not accept, he said in 1934, that in his religion 'there should be a single human being considered lower than myself'. ${ }^{33}$ Besides more significantly Gandhi was conscious of hierarchies among dalits themselves. The scheduled castes, he said in 1937, 'cannot be expected to appreciate and accept ex-cathedra usages that discriminate between savarnas and avarnas and between the different groups among the avarnas themselves, as these smack of invidiousness and offend against reason'. ${ }^{34}$ His sensitivity about irrational character of the caste system shows that he was fully open to the purely notional or dimensional interpretation of the Caturvarna.

We know that Gandhi wanted to have undivided general elections for the untouchables and virulently opposed the latter to have a separate electorate. We can say that Gandhi's ideal of merging the Dalits within the mainstream population may well be reconciled with the paradigmatic version of the Caturvarna that we have adopted. We may also add - though tentatively — that keeping a separate electorate for the Dalits may have looked like an artificial way to keep one personality trend or one dimension of measurement in strict segregation from the other-which in the long run will freeze the Dalits into a fixed identity, instead of liberating them from the latter.

Many eloquent and moving appeals were made by Gandhi against untouchability-when he said that if we do not incorporate the untouchables into the mainstream society the very notion of swaraj will turn out to be a vacuous one. 'The advice I receive from one and all is that if I do not exclude the Antyajas [untouchables] from the national schools, the movement for swaraj [self-rule] will end in smoke. If I have even a little of the Vaishnava in me, God will also vouchsafe me the strength to reject the swaraj which may be won by abandoning the Antyajas, ${ }^{35}$... it is equally necessary for us to give peace to the Panchama (untouchables) before we can with any show of justice or self respect talk of Swaraj....Hence for me the movement of swaraj is a movement of self-purification'. ${ }^{36}$ Now what we have sought to argue in the first section is that the Caturvarnas being conceptual dimensions or paradigms - they can neither be segregated nor merged forcefully_rather keeping a self-governed balance amongst them constitutes the very essence of niṣkāma karma. It is this niṣkāma karma that Gandhi is referring to by the term 'self-purification',

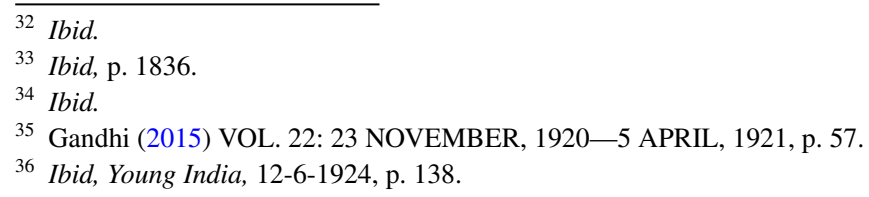


and his demand of incorporating Dalits within the general population as amounting to an exercise of self-purification seems to be in accordance with this paradigmatic re-construal of the Caturvarna. If swaraj is freedom then it should be merged with the moral character of the four paradigms and there is no freedom without the emancipation of the Dalits. Freedom is the freedom from external constraint-like greed or utilitarian agendas - and hence the very notion of a separate class like Dalits is both morally repugnant and conceptually invalid-like the notion of pure length without breadth or depth and vice versa.

Gandhi further said-'When I ask you to purify your hearts of untouchability, I ask of you nothing less than this - that you should believe in the fundamental unity and equality of man. I invite you all to forget that there are any distinctions of high and low among the children of one and the same God'. ${ }^{37}$ Here Gandhi's words are sensitive not only to the moral flaw of the purportedly fixed essence of each varna, but rather to the conceptual flaw in such categorizations. Perhaps Ambedkar's demand for a separate electorate for the Dalits hurt Gandhi's sense of the natural interpenetration of the four paradigms - which led him to make such extreme comments about the propriety of his own death-had Dr. Ambedkar taken up decided to go against the Poona Pact and punished the so-called caste Hindus for their 'sins of generation'. ${ }^{38}$

How to interpret Gandhi's comments about himself suffering more as an untouchable since he was a convert to untouchability and not born into it? We have seen how the purely conceptual paradigms of Caturvarṇa degenerated into arbitrary sects assuming a philosophical mask. Perhaps Gandhi implied that discarding one fake mask-viz. that of a Vaiśya and putting on another fake identity of a Dalit confines him into a more alien form of oppression. This act of putting off one mask and wearing another may also be conceived as wearing mask of a mask-shadow of a shadow-being twice removed from reality and yielding to doubly intense form of intellectual and moral oppression.

Lastly Gandhi's remarks about the issue of scavenging invite more detailed controversies. 'In my humble opinion, the dirt that soils the scavenger is physical and can be easily removed. But there are those who have become soiled with untruth and hypocrisy, and this dirt is so subtle that it is very difficult to remove it. If there are any untouchables, they are the people who are filled with untruth and hypocrisy..., 39 'Even if scavengers, potters and barbers are offered the fullest payment, they may or may not serve, as they please; they have a right to decide. If we, too, acknowledge this right of theirs, we shall have qualified ourselves for full swaraj'. ${ }^{40}$ 'Scavenger, I employ that word in all its meaning. If the members would get out and lend a helping hand to clean up the city, literally and morally, they would be doing a great work'. ${ }^{41}$ Further- 'If we had not despised professions which required one to use

\footnotetext{
37 Ibid, Harijan, 16-2-1934, p. 146.

38 Ibid, VOL. 57: 5 SEPTEMBER, 1932-15 NOVEMBER, 1932, p. 123.

39 Ibid, VOL. 16: 1 SEPTEMBER, 1917-23 APRIL, 1918, p. 138.

40 Ibid, VOL.17: 26 APRIL, 1918 - APRIL, 1919, p. 30.

41 Ibid, quoted from Young India, 25-2-1920, p. 336.
} 
one's hands and feet, we would not have fallen into this unhappy state and graduates would have felt no shame in working even as scavengers' ${ }^{42}$

In accordance with the dimensional model of Caturvarna that we have accepted, we can say that scavenging should be characterized by a synthesis of the three aspects of the gunas - the săttvik mark will consist in cognizing the principles of preserving ecology and environment, the rājasik aspect of scavenging implements them into sustained actions to harmonize theory and practice, whereas the last aspect of tamas would perhaps consist in a dedication to the gritty details of actual labour. It is the synthesis of the four dimensions in the act of scavenging that would render it into a noble profession. In all probability Gandhi did not call the so-called śüdras to practice scavenging, rather he had called on all individuals to be sensitive to the sāttvik, rājasik and tāmasik aspects of scavenging. If he had really insisted on a rightful imposition of the scavenging function on to the sūdras-it would have been the most scandalous and cruel joke, as Ambedkar remarked.

\section{Concluding Remarks}

Nauriya (2006) records that in 1945 Gandhi's position against the Caturvarna became quite definitive and in a new forward to an old anthology in Gujrati where he explicitly asserted that all his older statements on Caturvarna that do not cohere with his latest observations are to be rejected. And he even says: 'But there prevails only one varna today, that is of shudras, or you may call it, ati- 'shudras', or harijans or untouchables'. ${ }^{4}$

One of his latest comments on varṇa came in February 1947 where he said that caste must go if Hinduism is to survive, and yet qualifying that 'There was room for varna, as a duty'. According to him: 'This was true of all religions whether the name used was other than varna. What was a Muslim 'maulavi' or a Christian priest but a brahmin if he taught his flock its true duty, not for money but because he possessed the gift of interpretation? And this was true of the other divisions' ${ }^{44}$ Here he seems to be upholding neither a hereditary categorization nor a psychological determinism - but merely certain pronounced dispositions in one's character and personality which would motivate him to deliver the best performance in a desireless fashion for the sake of duty - unhindered by a false split between an action and its consequences.

Reading Gandhi's view on varna in the paradigmatic mould is apparently nothing new-many stalwart commentators have taken Gandhi to have retained an idealized version of the varṇa system. ${ }^{45} \mathrm{I}$ have sought to add a new perspective to this trend of

\footnotetext{
42 Ibid, VOL. 19: 29 SEPTEMBER, 1919-24 MARCH, 1920, p. 105.

43 Nauria (2006), p. 1837.

44 Ibid.

45 For instance, Singh (2014), has presented a comparative analysis of the commentaries of Thomas Pantham, Ramchandra Guha and Partha Chatterjee - where Gandhi's idealistic approach to Caturvarna has been differently deployed to settle (or unsettle) the Gandhi-Ambedkar debate. However, their idealistic reading has a focus different from the agenda of this paper.
} 
thought-viz. that one requires a systematic and rigourous critique of psychological determinism (constituted by definite proportions of trigunas and corresponding store of samskāras) or any other foundational categorization, in order to sustain the idealized reading of the varna system. It is through a long and tortuous journey that Gandhi's initial concessions to the principle of Caturvarna finally ended up with an unreserved dismissal of any kind of genetic or sāmskārik pre-destiny. It is the entire history of his life and his nation that showed him how ethics-in the true sense of the term-has to break free from any metaphysical, psychological or utilitarian impositions.

\section{References}

Aranya, S. S. H. (1369 (Bengali Calendar)/1962 (Christian Calendar)). KarmaTattva. Madhupur: Kapil Math.

Ghosh, A. (1997a). Human cycle, the ideal of human unity, war and self-determination. Pondicherry: Sri Aurobindo Ashram Private Limited.

Ghosh, A. (1997b). Essays on the Gita. Pondicherry: Sri Aurobindo Ashram Private Limited.

Ghosh, A. (1999). The synthesis of yoga. Pondicherry: Sri Aurobindo Ashram Private Limited.

Basu, S. (1995). The caste system of India-An Aurobinonian perspective. Sri Aurobindo Mandir Annual, 54, 136-154.

Brecht, B. (1939) Life of Galelio. Digitalized by RevSocialist for Socialist Stories (p 98). Web. www. socialiststories.com/liberate/Life\%20of\%20Galileo\%20-\%20Bertolt\%20Brecht.pdf. Retrieved March 21, 2020.

Chakrabarti, T. K. (2010). In defence of Varṇa Vyavasthā: A rejoinder to Ambedkar. Jadavpur Journal of Philosophy, 20(3), 35-42.

Chattopadhyay, B. (1401 (Bengali Calendar/1995 Christian Calendar)) Bankim Rachanabali II. Calcutta: Shishu Sahitya Sangsad Pvt Ltd.

Gandhi, M. K. (2015). Collected works of Mahatma Gandhi. Seattle: Kindle Edition.

Kapali Sastry, T. V. (1948). Sri Aurobindo: Lights on the teachings. Madras: Sri Aurobindo Library.

Mitra, E. (2014). 'Understanding Yudhisthira's actions: Recasting Karmayoga in a Wittgenstein mould. In A. Chakrabarti \& S. Bandyopadhyay (Eds.), Mahabharata now: Narration, aesthetics, ethics. London: Routledge.

Nauriya, A. (2006). Gandhi's little-known critique of varna. Economic and Political Weekly, 41(19), $1835-1838$.

Radhakrishnan, S. (1949). The BhagavadGītā. London: George Allen \& Unwin LTD.

Singh, A. (2014). Gandhi and Ambedkar: Irreconciliable differences? International Journal of Hindu Studies, 18(3), 413-449.

Strohmeirer, J. (2009). The Bhagavad Gita according to Gandhi. Berkeley: North Atlantic Book.

Subbannachar, N. V. (1966). Social psychology: The integral approach. Calcutta: Scientific Book Agency.

Venkatesananda, S. (2001). The yoga sutras of Patanjali. Delhi: Motilal Benarasi Dass Publishers Private Limited.

Web. www.sanskritweb.net/rigveda/rv10-086.pdf, verse 12. Retrieved March 27, 2020.

Publisher's Note Springer Nature remains neutral with regard to jurisdictional claims in published maps and institutional affiliations. 